\title{
РУССКАЯ ПОЛЯРНАЯ ЭКСПЕДИЦИЯ (1901-1902 ГГ.): СТРАНИЦЫ ИЗ АРХИВА РУДНО-ПЕТРОГРАФИЧЕСКОГО МУЗЕЯ ИГЕМ РАН И ФОНДОВ БИБЛИОТЕКИ ГЕОЛОГИЧЕСКОЙ ЛИТЕРАТУРЫ БЕН РАН
}

\author{
ЧАСТЬ 1. РУССКАЯ ПОЛЯРНАЯ \\ ЭКСПЕДИЦИЯ (1901-1902 ГГ.): ЦЕЛИ И ЗАДАЧИ
}

\author{
А.Я. Докучаев ${ }^{1}$, Г.-Р. Крехан ${ }^{2}$, А.В. Каргин ${ }^{3}$, \\ Ф.В. Кулаков ${ }^{4}$, Е.Б. Курдюков ${ }^{5}$, А.Б. Лексин ${ }^{6}$, К.В. Лобанов ${ }^{7}$, \\ М.В. Полякова ${ }^{8}$, В.Н. Смольянинова ${ }^{9}$, Е.В. Юткина ${ }^{10}$
}

\begin{abstract}
Аннотация. В архиве Рудно-петрографрического музея ИГЕМ РАН хранятся папки (дела) Геологического и минералогического музея имени Петра Великого Императорской академии наук с уникальными документами на русском, немецком и итальянском языках многих выдающихся российских и зарубежных ученых и исследователей, а основу фондов Библиотеки геологической литературы БЕН РАН составляют оттиски, журналы и книги из библиотеки при Минералогическом музее, основанной академиком Ф.Б. Шмидтом в 1880 году.

В статье, написанной по материалам личной переписки между начальником Русской полярной экспедиции (РПЭ) Э.В. Толлем (Толем) и председателем Особой комиссии по снаряжению РПЭ при Императорской академии наук академиком Ф.Б. Шмидтом, хранящейся в архивах музея, впервые освещены события, повлиявшие на реализацию задач РПЭ.

Ключевые слова: Русская полярная экспедиция, Земля Санникова, Э.В. Толль, Ф.Б. Шмидт, Н.Н. Коломейцев, А.В. Колчак, Ф.А. Матисен, Рудно-петрографический музей ИГЕМ РАН, Библиотека геологической литературы БЕН РАН.
\end{abstract}

\section{ВВЕДЕНИЕ}

Настоящей публикацией открывается серия статей по истории освоения Северного морского пути и прилегающих к нему территорий, входивших в круг геополитических интересов России на рубеже XIX и XX веков. Статьи основаны на архивных материалах Рудно-петрографического музея Института геологии рудных месторождений, петрографии, минералогии и геохимии (РПМ ИГЕМ) РАН - личной переписке и дневниках выдающихся ученых и политических деятелей России, что позволяет уточнить обширную информацию по истории великих географических и геологических открытий того периода.

В РПМ ИГЕМ хранятся геологические коллекции и папки (дела) Геологического и минералогического музея имени Петра Великого Императорской академии наук, с уникальными архивными документами (письмами, почтовыми открытками, рапортами, пояснительными записками, геологическими схемами, ведомостями к коллекциям и др.) на русском, немецком и итальянском языках многих выдающихся российских и зарубежных ученых и исследователей, в том числе Э.В. Толля [1].

РПМ ИГЕМ и Минералогический музей имени А.Е. Ферсмана РАН в период времени 1836-1898 гг. входили в состав Минералогического музея Императорской академии наук, с 1898 по 1906 гг. - в состав Геологического музея Императорской академии наук, а с 1906 г. - Геологического и минералогического музея имени Петра Великого Императорской академии наук [6].

Коллекции РПМ ИГЕМ берут свое начало от Минерального кабинета Санкт-Петербургской кунсткамеры. Одной из наиболее ранних является коллекция А.Ф. Постельса по результатам кругосветного путешествия на военном шлюпе «Сенявин» под командованием капитана Ф.П. Литке (1826-1829 гг.); отдельные экспонаты появились в начале XIX

\footnotetext{
${ }^{1}$ Докучаев Александр Яковлевич - к. г.-м. н., ИГЕМ РАН, г. Москва, в. н. с., заведующий Рудно-петрографическим сектором-музеем (alexandre-dokuchayev@yandex.ru).

${ }^{2}$ Крехан Герд-Райнер - геолог. Граубештрассе 30, D-39116, Магдебург, ФРГ (krehahn@kabelmail.de).

${ }^{3}$ Каргин Алексей Владимирович - к. г.-м. н., в. н. с., ИГЕМ РАН, г. Москва (kargin-igem@mail.ru).

${ }^{4}$ Кулаков Филипп Викторович - м. н. с., ИГЕМ PAH, г. Москва (kolin_dom@mail.ru).

${ }^{5}$ Курдюков Евгений Борисович - к. г.-м. н., ст. н. с., ИГЕМ РАН, г. Москва (e-kurdyukov@yandex.ru).

6Лексин Алексей Борисович - ведущий программист, ИГЕМ PAH, г. Москва (lexin@igem.ru).

7Лобанов Константин Валентинович - чл.-корр. РАН, директор ИГЕМ РАН, г. Москва.

${ }^{8}$ Полякова Марина Валентиновна - заведующая Библиотекой геологической литературы (ОГЛ) БЕН РАН (ogl@igem.ru).

${ }^{9}$ Смольянинова Вера Николаевна - к. г.-м. н., cm. н. с., ИГЕМ РАН, г. Москва (smolvernik@yandex.ru).

${ }^{10}$ Юткина Евгения Владимировна - к. г.-м. н., cm. н. с., ИГЕМ РАН, г. Москва (eyutkina@gmail.com).
} 
в. и вошли в «Краткую опись Минеральному кабинету Императорской Академии наук по новому онаго расположению в 1820 году» (В. Севергин, 1821). Базовой для РПМ ИГЕМ является «Систематическая петрографическая коллекция Геологического и минералогического музея имени Петра Великого Императорской академии наук»), основанная в 1908 г. академиком В.И. Вернадским.

Авторами и адресатами хранящейся в архиве РПМ ИГЕМ переписки являлись его выдающиеся сотрудники и коллекторы - академики В.И. Вернадский, В.А. Обручев, Ф.Н. Чернышёв, Ф.Б. Шмидт, Ф.Ю. Левинсон-Лессинг и многие другие.

Коллекции РПМ ИГЕМ сопровождаются архивом документов. В первую очередь, это коллекция горных пород полярных районов Сибири (292 образца) Э.В. Толля по данным экспедиций 1885-1902 гг.; коллекция Карла Ванотти продуктов исторически датированных извержений вулкана Везувий (начиная с 79 г.), коллекция Марио Джемелларо лавовых потоков вулкана Этна (датированных начиная с 1535 г., 186 образцов), а также многих других выдающихся исследователей.

В РПМ ИГЕМ созданы экспозиции, посвященные: 300-летию основания первого в России государственного общедоступного музея - Кунсткамеры; 115-летию Русской Полярной экспедиции (1900-1902 гг.); 100-летию Гидрографической экспедиции Северного Ледовитого океана (1910-1915 гг.); 100-летию Мурманской железной дороги; 115-летию шведско-русской экспедиции по проведению градусных измерений на архипелаге Шпицберген (1899-1902 гг.); 105-летию Шпицбергенской (русской научно-промысловой) экспедиции (19111912 гг.); 170-летию открытия Онежских петроглифов профеессором К.И. Гревингком (1848 г.) и др.

Сопровождающая коллекции информация в текстовом, графическом и картографическом виде хранится в электронной базе данных и в архиве РПМ ИГЕМ, а в виде отчетов и статей - в Библиотеке геологической литературы БЕН РАН, с которой РПМ ИГЕМ тесно сотрудничает.

В период с 1873 по 1900 годы Минералогический (Геологический) музей ИАН возглавлял академик Фёдор Богданович (Фридрих Карл) Шмидт, выдающийся русский геолог, ботаник и палеонтолог. В 1880 г. он основал специальную библиотеку при Минералогическом музее (после смерти Ф.Б. Шмидта в 1908 г. оставшаяся часть его личной библиотеки была передана в Музей). Ф.Б. Шмидт был председателем Особой комиссии по снаряжению Русской полярной экспедиции (РПЭ, 1900-1902 гг.), а несколько ранее - одним из руководителей и членом Особой комиссии по градусным измерениям на островах Шпицберген (1899-1901 гг.).

Перипетии Русской полярной экспедиции (РПЭ) детально изложены в дневниках и отчетах ее участников и организаторов (рис. 1, 2) - Эдуарда Васильевича Толля, Александра Васильевича Колчака, Михаила Ивановича Бруснева, Николая Николаевича Коломейцева (Коломейцова), Фёдора Андре-

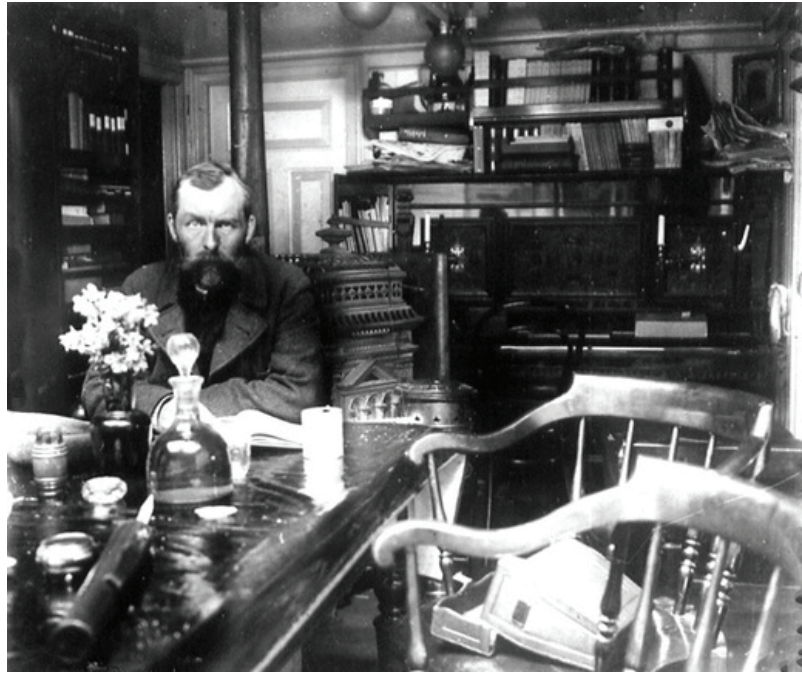

Puc. 1. Барон Э.В. Толль в кают-компании яхты «Заря» (архив семьи Виттенбург) // URL: https:// lenta.ru/ articles/2016/05/13/arctickolchak

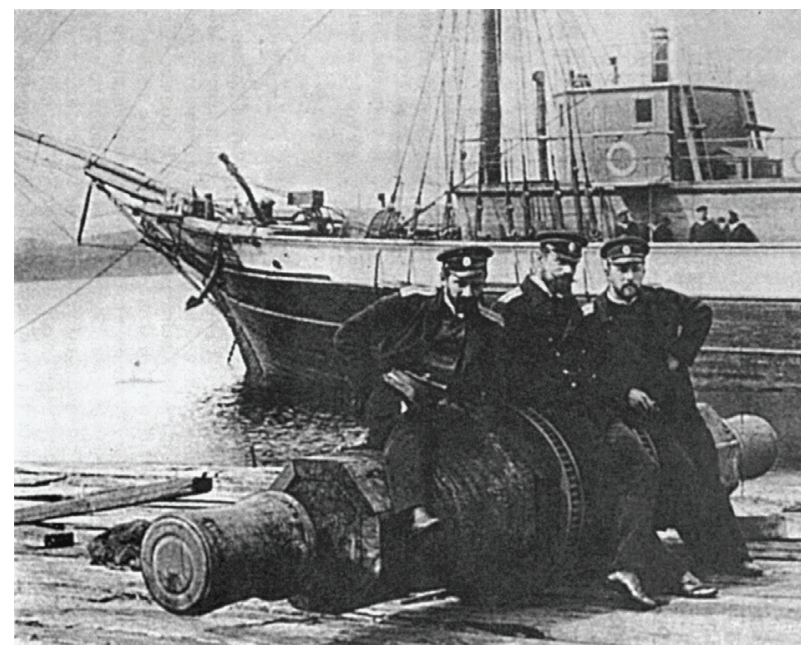

Puc. 2. Члены экспедиции Толля лейтенанты

А.В. Колчак, Н.Н. Коломейцев (Коломейцов), Ф.А. Матисен у борта яхты «Заря» // URL: https://howlingpixel.com/wiki-ru/

евича Матисена, Фердинанда Фердинандовича Врангеля, Алексея Андреевича Бялыницкого-Бирули и др. [5, 11-13, 16, 21, 22 и др.], а также в научнопопулярной литературе [4, 8, 15, 24, 25 и др.].

Дополнительные сведения о РПЭ содержатся в отчетах «О деятельности Императорской Академии наук», хранящихся в головной библиотеке отделения «Науки о Земле» РАН $[2,9,10]$, а также доступны на сайте Национальной электронной библиотеки.

Цитированные ниже документы и тексты даются курсивом и в оригинале, с сохранением авторской орфографии и пунктуации. Тексты приведены, по возможности, без купюр. Для исторической достоверности, в случаях, когда событие освещено в нескольких текстах, предпочтение отдавалось документальному свидетельству очевидца, а не про- 
токолу заседания или литературно переработанному материалу.

\section{ЦЕЛИ И ЗАДАЧИ РУССКОЙ ПОЛЯРНОЙ ЭКСПЕДИЦИИ}

«Мы, русские, пользуясь опытом наших предков, уже по географическому положению лучше всех других наций в состоянии организовать экспедиции для открытия архипелага, лежащаго на север от наших Ново-Сибирских островов и исполнить их так, чтобы результаты были и счастливы, и плодотворны».

Барон Э.В. Толль,

начальник Русской Полярной экспедиции [5].

«...мы сами нашли наши новые земли. Но хочется думать, хочется верить, что и для исследования этих новых земель мы не будем ждать прихода чужих людей, а найдем у себя, и найдем скоро, и возможности, и сведущих ученых, и средства».

Доктор Л.М. Старокадомский, судовой врач транспорта «Таймыр» Гидрографической экспедиции Северного

Ледовитого океана 1909-1915 гг. [20].

По плану Э.В. Толля, «на одних собачьих нартах, в виду имеющихся полыней, дойти до Санниковой земли невозможно. Поэтому единственным способом является плаванье на судне... Вследствие тумана Нансен не видел эту сушу, но стада куличков, летевших здесь на $78^{\circ}$ с. шир. ему на встречу от севера к югу, убеждают в том, что тут безусловно находится земля. Правда, Fram [судно норвежского полярного исследователя Фритьофра Нансена] замерз между льдинами как раз недалеко от о-ва Санникова [в 1895-1896 гг.]. Поэтому следует в первый год... отправить подходящее судно через Карское море и мимо мыса Челюскина в устье Лены и выше по реке Лене до удобнаго места зимовки у города Якутска или даже Витимска... Экспедиция может производить изследования по сибирскому берегу. На зиму экспедиция вернется в Европу... Снарядившись лучшими ... собаками, оленями, ... лошадьми экспедиция начинает свое плаванье из устья Лены... До начала плавания одна партия, в марте месяце, отправляется на собаках на Ново-Сибирские острова для устройства спасательных депо... Этот отряд... вернется заблаговременно к устью Лены, или останется на о-ве Котельном, и судно заберет его по пути... плаванья на север. Добравшись на судне до земли Санникова или о-ва Беннета, экспедиция выберет себе место зимовки и поставит себе дом для годовой станции... Между тем судно вернется опять к устью Лены. Во время летних месяцев третяго года экспедиция будет производить окрытия и изследования архипелага до августа месяца, после чего судно, отправившись вторично из устья Лены на о-в Санникова, увезет экспедицию домой» [5, 23].

На одном из последних заседаний Особой ко- миссии по снаряжению РПЭ, проходившем под личным председательством Президента Академии наук Великого князя Константина Константиновича (Романова), Э.В. Толль представил существенные изменения в первоначальный план РПЭ [5] (рис. 3):

1. «... вместо того чтобы в первую навигацию проникнуть на зимовку в р. Лену, предполагается экспедицию на шхуне «Заря» привести на первую зимовку в одну из бухт, расположенных на восточном берегу Таймырскаго полуострова. Впродолжение зимы члены экспедиции производили бы экскурсии для изследования этой страны, ... так как [Александр Фёдорович] Миддендорф в знаменитое свое путешествие в 1843 г. посетил лишь западную часть полуострова».

2. «C открытием навигации... на судне... проникнуть до Земли Санникова и... обследовать ближайшее пространство моря. Выбрав... удобную якорную стоянку в Ново-Сибирском архипелаге или на одном из вновь открытых островов, экспедиция вторую зиму проведет у этого убежища, производя на санях научныя экскурсии. К этому времени... вспомогательная экспедиция проникнет... на санях на Ново-Сибирские острова, устроив на них... склады провианта, на тот случай, если бы шхуна «Заря» была затерта льдами и экипажу пришлось бы отступать на санях или лодках. ... Вспомогательная экспедиция... произведет дальнейшее обследование Ново-Сибирских островов».

3. «С открытием навигации 1903 г. экспедиция предполагает морем пройти в Берингов пролив, закончив этим главную свою программу... Экспедиция снабжена провиантом на 4 года, хотя продолжительность ея расчитана на 2 года».

\section{РЕАЛИЗАЦИЯ ПЛАНА И ОСНОВНЫЕ ПРИЧИНЫ НЕУДАЧИ РУССКОЙ ПОЛЯРНОЙ ЭКСПЕДИЦИИ}

«В последнее время только иностранцы - американцы с одной и скандинавцы с другой стороны - взяли на себя совершить то, что следовало нам самим исполнить... и если мы не возьмемся за дело, не пройдет и двух-трех лет, как отнято будет от нас последнее поле действия на севере от сибирского берега - Земля Санникова»

Барон Э.В. Толль,

начальник Русской Полярной экспедиции.

«Одной из слабых сторон нашей экспедиции была крайняя сиюминутность её, мы всё время торопились как на пожар...: скорее, скорее.

Эта черта, насколько я помню, погубила многие экспедиции...»

А.В. Колчак,
лейтенант фрлота, гидрограф Русской Полярной экспедиции.

План Э.В. Толля был поддержан Фритьофом Нансеном [5]: «Во-первых, ... я с ним согласен относительно вероятности нахождения островов к северу от Ново-Сибирских островов. Мы знаем 


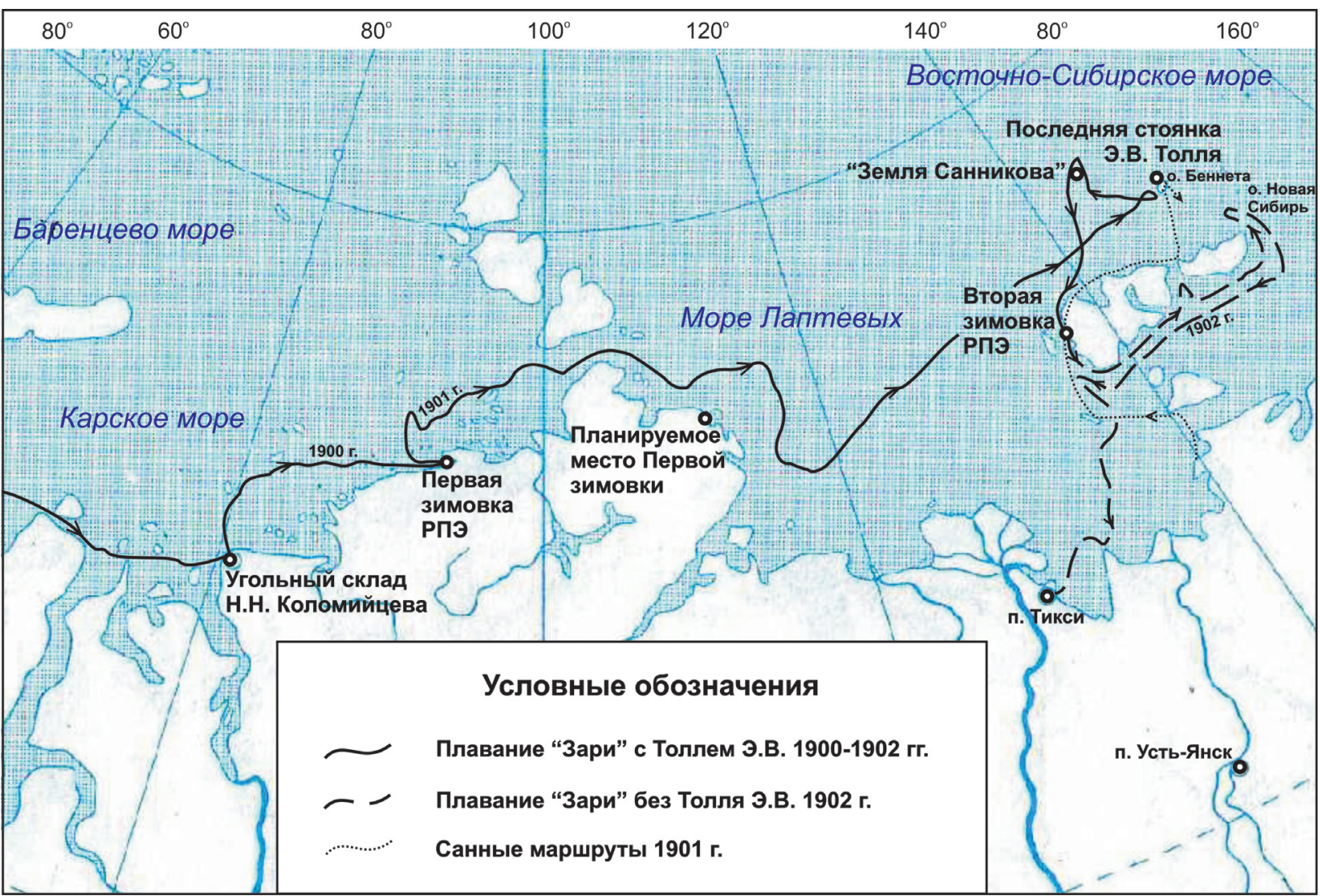

Puc. 3. Маршруты Русской полярной экспедиции на яхте «Заря» 1900-1902 гг. ([22], с уточнениями)

землю Беннета и землю Санникова, из которых последнюю барон Толль сам видел, но там может быть и больше таких островов... изследование этих земель было бы подвигом величайшей научной важности... земли эти достижимы на судне каждое лето и думаю, что достижима на судне даже земля Беннета... Я искренне надеюсь, что эта экспедиция вскоре осуществится...

...я не думаю, чтобы можно было посоветовать идти с судном восточнее мыса Челюскина к устьям Лены в том же году, в котором предположено было бы вести экспедицию от Сибирскаго берега на Санникову Землю или на острова к северу оттуда... я опасаюсь, что судно достигнет устьев Лены так поздно, что останется мало времени для экспедиции к северу.

...Наконец,... какое судно я бы предпочел для этой цели: ледокол ли адмирала Макарова, или ... китобой. ... Потеря ... китобоя не представит потери, какой бы Россия не могла перенести с легкостью».

«...план барона Толля вряд ли осуществился бы, если бы он не встретил мощную поддержку в лице Августейшаго Президента Императорской Академии Наук [Великий князь Константин Константинович Романов]. Встав на ту точку зрения, что изследование вод, омывающих наши Сибирские берега, и открытие ближайших к ним островов и земель завещано нам нашим славным прошлым, а в будущем может даже получить значение государственное, Его Императорское Высочество лично доложил Государю Императору о проекте русской полярной экспедиции. Его Величеству благоугодно было повелеть, чтобы из государственного казначейства была отпущена необходимая сумма» [5].

Осенью 1899 года Э.В. Толль после осмотра в портах Норвегии нескольких судов остановился на паровом тюленебойном барке «Harald Haarfoger».

При переоборудовании барка «Н.Н. Коломейцов применил весь свой опыт и знание морского дела. На «Заре», как второй помощник, я исполнял обязанности ревизора, лейтенант Матисен - старшего офрицера. Выработанный и привычный нам режим военного корабля вообще применялся у нас, насколько это было возможно. Работали мы все дружно и весело...» [14].

Суда этого типа отличались большим запасом прочности, обладали хорошей поворотливостью и малым радиусом циркуляции, облегчавшим их управление во время качки и плавания в разбитом льде. На эллинге Колина Арчера (известного строителя «Фрама» для экспедиции Ф. Нансена) судно было приспособлено для целей РПЭ, для чего были сделаны внутренние переделки и устройства.

Из-за малочисленности команды парусное барковое вооружение было изменено: прямые паруса были оставлены только на фрок мачте, поэтому по

\section{BECTHИK Trom 18




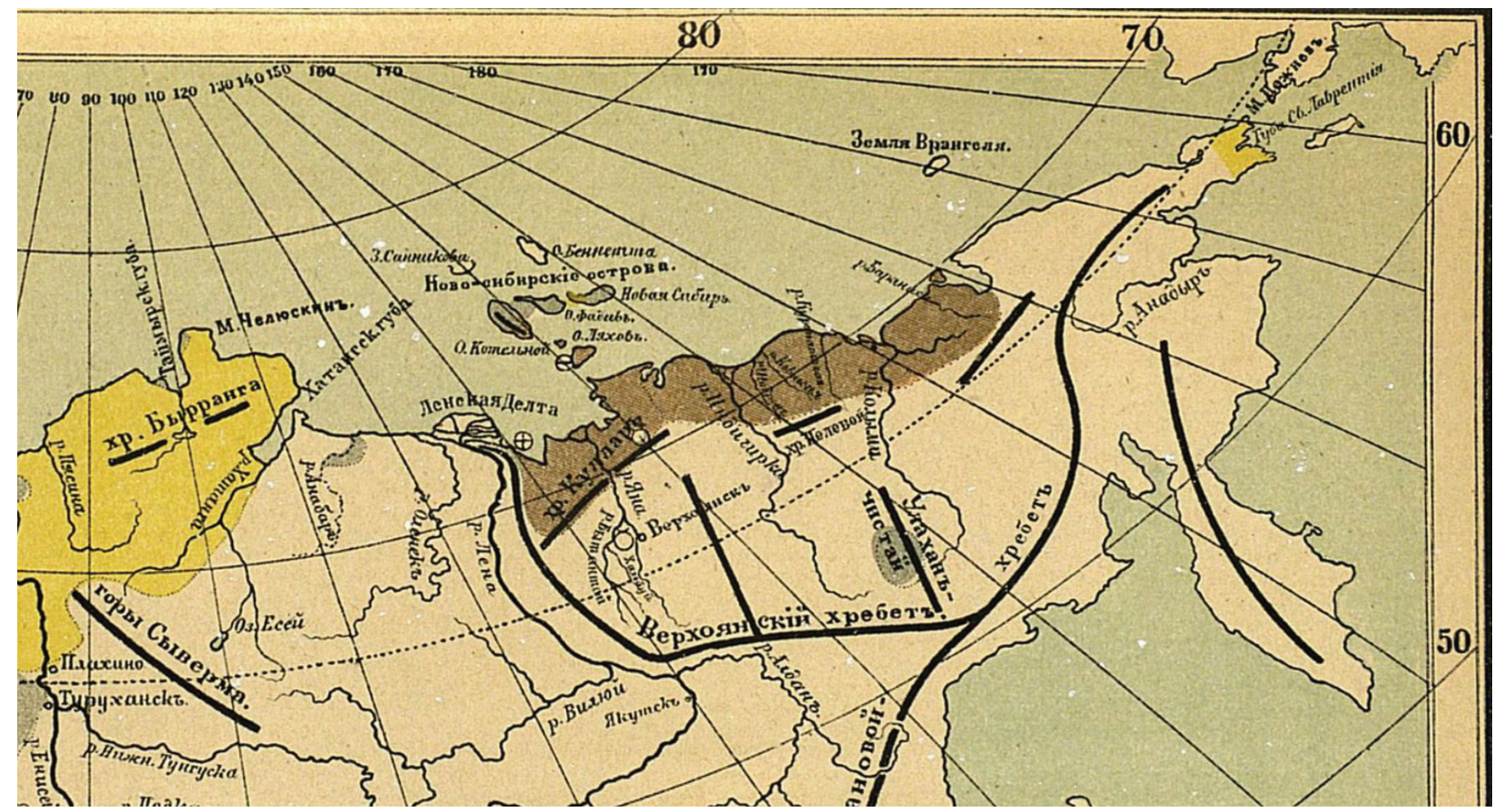

Puc. 4. Фрагмент «Карты ледниковых отложений Сибири» масштаба $1: 40.000 .000$, на которую Э.В. Толль нанес положение Земли Санникова [23]

парусному вооружению яхта «Заря» отвечала типу шхуны-барка или баркентины.

В машинном отделении, кроме полного ремонта машины и котла, было устроено помещение для 4 человек машинной команды, добавочная угольная яма, установлены турбодинамо для электрического освещения и токарный станок.

На «Заре» находился паровой катер, два 26-футовых китобойных вельбота, один 24-футовый спасательный вельбот образца, принятого в военном фолоте, четырехвесельная и двухвесельная шлюпки; имелись запасный руль и штурвал, а также запасной винт. В октябре 1899 года «Заря» получила аттестат о годности к плаванию на три года.

Сразу после покупки судно было переименовано в яхту «Заря». Несмотря на то, что большая часть команды судна была укомплектована матросами военного фрлота, «Заря» несла не Андреевский кормовой фрлаг кораблей ВМФ Российской Империи, а фрлаг Невского яхт-клуба. Невский яхт-клуб был создан незадолго до этого, в 1894 году; устав клуба был утвержден императором Николаем II, поэтому клуб именовался «Высочайше утвержденным». Главным направлением в деятельности Невского яхт-клуба были гонки, преимущественно парусные. Успех норвежской экспедиции Ф. Нансена на «Фраме» (1893-1896 гг.) делал «затронутый Толлем вопрос очередным, так сказать, модным вопросом. К тому же нашелся покровитель науки (не пожелавший быть названным), который для почина предоставил в распоряжение Б. Толля сумму в 5000 р.c.» [5].

А.В. Колчак указывал впоследствии, что «Заря» фрактически не прошла ходовых испытаний, а сразу отправилась выполнять поставленные перед РПЭ задачи: «Первое плавание из Норвегии сразу выяснило недостатки и непригодность некоторых людей из команды и дало основание для удаления их и заменой другими. Перемена весьма важная, и уже одно это указывает на необходимость хотя бы короткого пробного плавания, где лучше всего выясняются на деле как достоинства судна, так и пригодность личного состава» [14].

При прибытии в Петербург «Зарю» встретила только одна большая паровая яхта под фолагом Императорского яхт-клуба. «Нельзя сказать, чтобы проводы «Зари» [из Кронштадта] были особенно торжественны; нас провожало небольшое общество добрых и близких знакомых, и только... Вообще в Петербурге, не говоря уже про всю Россию, многие не знали про нашу экспедицию... Интересовалось нами, конечно, Морское ведомство, но и оно ограничивалось лишь немногими компетентными в морском деле представителями, такими, как адмирал [С.О.] Макаров [главный командир Кронштадтского порта и губернатор Кронштадта], полковник А.Н. Крылов, капитан [А.Г.] Цвингман [в 1901-1902 гг. командир ледокола «Ермак», которого на этом посту в 1902-1904 гг. сменил Н.Н. Коломейцев]...» [14].

В 1885-1886 гг. Э.В. Толль был участником экспедиции А.А. Бунге на Новосибирские острова (выделение текста сделано нами): «... на острове Беннета найдены траппы, а на Земле Санникова, которую я видел издали, с севернаго конца острова Котельнаго во время ясной погоды летом 1886 г., замечаются столовыя горы, по фоорме которых можно предполагать, что оне тоже трапповыя. Эти соображения позволяют допустить, что на севере от Ново-Сибирских островов нахо- 
дится еще архипелаг, быть может не меньшаго размера, чем острова Франца-Иосифра. Но мало того: простирание третичных слоев острова Новой Сибири указывает как раз на продолжение их в том месте, где виднеется Земля Санникова и где лежит остров Беннета. С последняго De Long доставил нам известие о нахождении залежей бураго угля. Мне кажется возможным предположение, что эти бурые угли относятся так же, как на Новой Сибири, к третичному периоду» [5]. Легендарную Землю Санникова Э.В. Толль нанес на карту, которую опубликовал в Записках Императорского РГО (рис. 4) [23].

В этом серьезном заблуждении скрыта еще одна причина неудачи РПЭ. Начальник экспедиции Э.В. Толль, рассчитывая на обнаружение залежей угля на Новосибирских островах, планировал решить задачу и пройти Северным морским путем в Берингов пролив за счет пополнения запасов на островах Новая Сибирь и Котельный, а также на архипелаге островов в районе Земли Санникова.

\section{КОНФЛИКТ МЕЖДУ Э.В. ТОЛЛЕМ И Н.Н. КОЛОМЕЙЦЕВЫМ}

Конфликт между начальником РПЭ Э.В. Толлем и капитаном «Зари» Н.Н. Коломейцевым зрел с самого начала экспедиции. Из письма главного зоолога экспедиции А.А. Бялыницкого-Бирули, адресованного библиотекарю Зоологического музея Р.Г. Шмидту [21]: «C 20 октября наступила полярная ночь. Первое время к судну иногда подходили медведи, и охота на них разнообразила наше времяпровождение, но скоро и это прекратилось. Все темное время зимы главное наше занятие было дежурство (раз в неделю) на метеорологической и магнитной станции, кроме того, мы могли вдосталь любоваться полярными сияниями и слушать гудение вьюги в снастях. От безделья начались у нас и скандалы: Вы, вероятно, еще в Екатерининской гавани слыхали, что начальник и командир не ладят между собой - здесь они вконец разладились, и командир собрался уезжать om нас» (Екатерининская гавань - незамерзающая гавань на выходе из Кольского залива, где находится Александровск-на-Мурмане, ныне - город Полярный).

Н.Н. Коломейцев считал, что команда на судне должна подчиняться Морскому уставу, и поэтому он должен иметь в своем распоряжении обоих морских офицеров - лейтенантов Ф.А. Матисена и А.В. Колчака: «Режим у нас был следующий: стояли мы и команда на три вахты, причем Коломейцов стоял вахты с четырех до восьми утра и дня, а остальное время Матисен и я сменяли друг друга... Стоянка на три вахты вообще нелегка, у нас на военных судах обыкновенно стоят по пять, при четырех уже жалуются на тяжесть вахтенной службы, но, простояв два арктических плавания на две вахты, я считаю, что при трех офицерах стоять вахты можно даже с командиром, так как через день представляется возможность спать и отдыхать целых восемь часов подряд» [14].

А.В. Колчак отметил следующие определяющие, но оставшиеся нерешенными организационные вопросы РПЭ ([25] - цитирование из [14]): «... Военный фрлаг - вещь крайне неудобная для такого рода плавания, какое нам предстояло...: во-первых, уже потому, что связанные с ним военное положение и порядок трудно применимы при малочисленной команде, условиях зимовки и проч. Толль никак не мог согласиться на это уже потому, что тогда он фрактически терял на судне всякую власть как не моряк и не могущий орактически командовать кораблем. Это было уже предвестником всего того, что имело быть в течение всей экспедиции, основная ошибка в организации которой состояла в том, что на судне и всем характере жизни, связанном с этим судном, главным распорядителем было лицо, не знающее морского дела... Накануне нашего ухода из Петербурга было заседание в Академии в присутствии Великого князя Константина Константиновича. На этом заседании были Толль, Коломейцов и я. Еще ранее Коломейцов настаивал на выяснении и точном определении прав и положения его как командира судна по отношению к начальнику экспедиции, я лично мало интересовался этими вопросами, считая их лишними и полагая, что все мы, связанные одними идеями и желаниями, можем обойтись без фрормальных бумаг и инструкций... Последствия, однако, показали, что все эти вопросы имели большое значение и отразились на ходе всей экспедиции. На этом же заседании была выдана коротенькая инструкция, в сущности говоря, ровно ничего не поясняющая да еще могущая быть истолкована в различных смыслах; ни научной программы, ни научных инструкций у нас никаких не было... инструкции и программы не нужны только тогда, когда они совершенно ясно и в определенной фооре выработаны руководителем предприятия - у нас этого не было. Основное противоречие, ясно осознанное мною только впоследствии, лежало в том, что начальником предприятия, носящего чисто морской характер, являлся человек совершенно не знакомый с управлением судна. Начальник полярного или арктического предприятия, конечно, должен иметь полную власть над всеми частями его и участниками; но власть тогда только власть, когда она существует реально... Какую фактическую власть может иметь на корабле человек, не могущий ни определиться, ни вести счисления, не могущий отдать якоря, дать ход машине, править рулем и не знающий всей той массы очень простых и, так сказать, органически привычных для моряка вещей? Конечно, раз судно плавает, фрактически начальником его и всех, кто на нем находится, является командир, как лицо компетентное во всех вопросах, связанных с плаванием и жизнью корабля. Смешно читать, например, у Нансена или даже в отчетах Толля вы- 

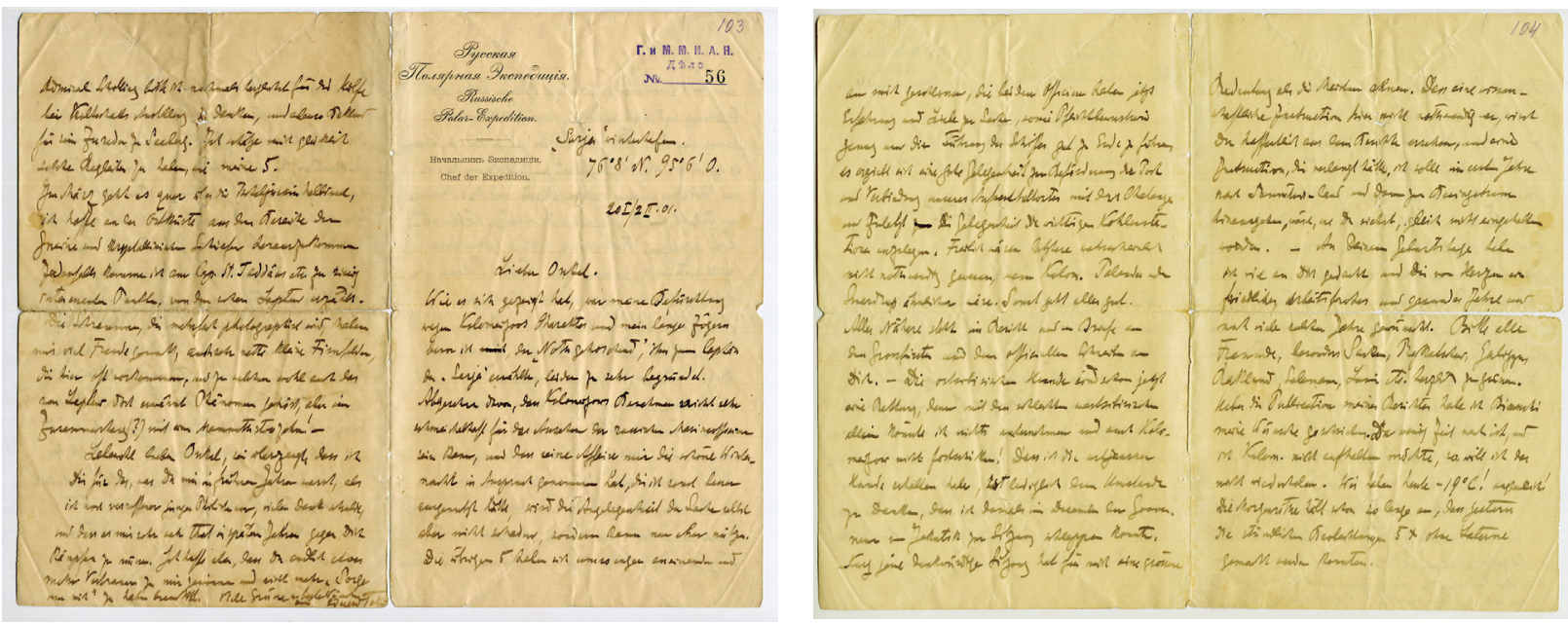

Puc. 5. Письмо Э.В. Толля академику Ф.Б. Шмидту, написанное шрифтом Зюттерлина на борту яхты «Заря» во время первой зимовки из района п-ова Таймыр 20 января / 2 февраля (старого стиля) 1901 года ([1], с. 103-104)

ражения: «Я снялся с якоря» или «Я изменил курс», когда эти «я», вероятно, не сумели бы выходить якоря и даже скомандовать рулевому, чтобы привести судно на желаемый румб. Англичане, как моряки, всегда прекрасно понимали эти вопросы...; я полагаю, что начальником должен быть просто образованный человек, ясно и определенно сознающий задачи и цель предприятия...; для начальника удобнее не иметь никакой специальности, а иметь побольше способностей управлять и руководить всем делом, ... а не «экскурсировать» с «казенными» целями, часто преследуя в ущерб всему свои специальные или «научные задачи»... Последнее заседание, в общем, ничего не прояснило...».

По мнению Э.В. Толля, «если же руки путешественника будут связаны различными инструкциями, и он не будет поэтому в состоянии пользоваться обстоятельствами и завоевать для науки хоть часть "terra incognita" северной Сибири, то, конечно, все труды и деньги на подобную экспедицию будут потрачены даром...» [23].

Любые промедления, даже ожидание подвоза необходимого количества угля перед стартом экспедиции, воспринимались Э.В. Толлем негативно. «Июля 25 (Августа 7) яхта «Заря пришла в Югорский Шар и в первом часу пополудни встала на якорь в бухте Варнека близ парохода «Пахтусов». В Югорском Шаре «Заря» должна была пополнить запас угля, доставленнаго ей на зафрахтованной шхуне, но вследствие сильных и противных ветров, шхуна ко времени прихода яхты «Заря» в Югорский Шар не поспела. В виду чрезвычайно благоприятных условий погоды и льдов, встреченных в проливе, начальник полярной экспедиции не решился терять драгоценнаго времени поджидая шхуну, помня, что в Ледовитом море иногда проволочка в несколько дней может задержать судно на месяцы. В третьем часу «Заря» снялась с якоря, при начавшемся легком SW и хорошей погоде, и пошла в глубь Югорскаго Шара. В тот же день ее видели из селения Хабарова, направляющеюся к выходу в Карское море. Ближайшия о себе известия экспедиция может отправить лишь по достижении Таймырскаго полуострова, где в одной из бухт восточнаго берега предполагается устроить первую зимовку» [5].

Приводим перевод фррагментов из писем Э.В. Толля академику Ф.Б. Шмидту, где он не скрывает своего отношения к Н.Н. Коломейцеву.

Первое письмо написано во время первой зимовки яхты «Заря» 20 января / 2 февраля (старого стиля) 1901 г. на борту судна, находившегося западнее полуострова Таймыр, в проливе между материком и островом Боневи (ныне пролив Заря) (рис. 5) (архив Рудно-петрографического музея ИГЕМ РАН, [1], с. 103-104).

«Заря», зимовка, $76^{\circ} 8^{\prime} \mathrm{N}, 95^{\circ} 6^{\prime} \mathrm{O}$.

20 / / 2 I/ [19]01.

Дорогой дядя.

Как оказалось, мое опасение по поводу характера Коломейцова и мое значительное промедление, прежде чем я подчинился «необходимости» выбрать его капитаном «Зари», к сожалению, было весьма обосновано.

Несмотря на то, что поведение Коломейцова не может быть очень лестно для престижа русских морских офицеров, и что его «афрера» отняла у меня прекрасную полярную ночь в августе, которую я иначе использовал бы лучше; однако, делу [это] не повредит, а, скорее, может быть полезно мне. Остальные пятеро более сблизились друг с другом и со мной; у обоих офицеров теперь есть и опыт и любовь к делу, а также достаточно добросовестности, чтобы довести до конца руководство кораблем; имеется хорошая возможность для доставки почты и для соединения нашего местопребывания ... и, в конце концов, возможность делать важные закладки угля. Конечно, последнее не нужно было бы, если бы Коломейцов был бы более сговорчивым. Все остальное нор- 
мально. Более подробно все отмечено в отчете и в письме Великому Князю, а также в официальном письме тебе. Восточносибирские собаки уже сейчас спасение, так как с менее подходящими только западносибирскими [собаками] я ничего не смог бы предпринять, а также не [смог бы] отправить Коломейцова!»

В дневниках Э.В. Толль [22] не уточняет, в чем заключалась «афера» Н.Н. Коломейцева.

Обострению конфрликта предшествовали следующие события, описанные А.А. БялыницкимБирулей [21]: «У Диксона мы простояли около недели [с 30 июля по 5 августа 1900 г.] (чистили машину), а затем пошли дальше на север. Скоро опять стал появляться лед, и однажды, обходя его, мы забрались в такие шхеры, что чуть-чуть выбрались - сели здесь несколько раз на мель, а один раз так скверно, что уже собирались «кончать плавание»... Кое-как удалось сняться с мели. Пробираясь среди густого льда, вдоль берега, мы кое-как дошли до большого залива. Дальше стоял сплошной лед. В этом открытом нами заливе (его назвали заливом Миддендорфа) мы простояли около месяца, выжидая перемены ветра, дувшего это время. SW-вые ветра прижали лед к берегу и загородили нам путь... Одно время казалось, что придется в этом заливе зазимовать - ветер упорно дул все c SW и не очищал моря. Но барону Толлю очень не хотелось зимовать, не пройдя Челюскина мыса, и поэтому было решено попытаться пробиться через лед, сколько возможно дальше. С большим трудом удалось выбраться из залива, так как лед закрыл выход, и истратив почти 1/3 нашего запаса угля, мы прошли еще около 100 верст среди густого льда, пробираясь из полыньи в полынью. Идя так, мы добрались до Норденшельдовых островов, но здесь оказалось, что между о-вами стоит не взломавшийся в течение года лед, постояли перед этой пробкой и пошли искать проход в другом месте; на севере все было занято льдом, а на юге был виден какой-то залив (здесь берег совершенно неверно картографирован прежними съемками). В этот залив мы и пошли - скоро оказалось, что это пролив, но все три его восточных выхода тоже оказались заткнутыми пробками цельного льда. Начало уже подмерзать - была середина сентября, и нам стало очевидно, что дальше мы не пройдем - придется здесь зимовать... Здесь три острова отделяют om моря канал, часть которого была уже открыта "Вегой» и названа Таймырским проливом [«Вега» - судно экспедиции А.Э. Норденшельда 1878-1879 гг.]. Через десять дней нас уже кругом окружил лед и мы вмерзли в него на целый год, до будущего августа. Началась зима».

26 сентября в 5 часов 30 минут вечера «Заря» окончательно встала на первую зимовку в Таймырском проливе. 28 сентября Э.В. Толль написал: «Угольный вопрос становится жгучим: на будущий год у нас остается угля только на 20 дней плавания, т.е. едва до Земли Санникова и ни шагу дальше... Эта местность может оказаться для нас роковой; лед в проливах стоит здесь долго и может уйти отсюда только в момент наступления зимы. Возможно, в будущем году мы окажемся в тех же условиях, и тогда придется остаться здесь на вторую зимовку... Коломейцев возражал против моей попытки выйти из пролива и горячо доказывал, что, рискуя слишком многим, мы добьемся очень малого (Матисена не было в это время)» [22].

Очевидно, что оба руководителя хорошо понимали: яхта «Заря» не сможет дойти до Берингова пролива, и в сложившейся ситуации судну суждено стать экспедиционной базой. Поэтому новый капитан судна лейтенант Ф.А. Матисен уже не будет препятствовать в использовании на судне угля для дополнительных научных экскурсий («делать важные закладки угля»).

20 октября Э.В. Толль сделал запись: «Я просил Коломейцева зайти ко мне, чтобы еще раз детально обсудить с ним угольный вопрос. Начнем с подсчета расхода угля в течение истекшего лета и подсчитаем расход угля на будущий год... Придется отставить мою поездку на Хатангу! Предпринять эту поездку казалось мне необходимым с двух точек зрения: 1) надо отправить письмо президенту Академии наук, чтобы возбудить вопрос об угольной базе на Котельном, и 2) надо использовать возможность объехать восточную часть Таймырского полуострова на всем его протяжении. В то же время мне представляется рискованным покинуть «Зарю», нет уверенности в том, что здесь все будет протекать благополучно, и неизвестно, как сложится в мое отсутствие работа на зимовке. Разрешение угольного вопроса в этом году еще терпит... Меня все больше беспокоит мысль, что мое присутствие абсолютно необходимо здесь не только как начальника, но и как посредника между двумя различно настроенными элементами в составе нашей экспедиции. Стало быть, я должен остаться и многое должно быть реорганизовано!» [22].

Э.В. Толль был очень раздражен, когда 6 октября казак С.И. Расторгуев, его спутник по экспедиции 1893 года, «сообщил, что тронтаеймовские собаки никуда не годятся, и заявил, что он вообще не умеет обращаться с упряжкой... и просил уволить его или же дать по крайней мере отпуск! Как вам это нравится - здесь, под 76¹0' с.ш. и $95^{\circ}$ в.д., говорить об отпуске?! Вскоре мне стало ясно, что у него не хватало мужества для этого путешествия; одновременно он затосковал по родине» [22].

К своему окончательному решению о дальнейшей судьбе Н.Н. Коломейцева и С.И. Расторгуева Э.В. Толль пришел 28 ноября: «Опять вопрос об угле! Остается единственный выход - уполномочить лейтенанта Коломейцева организовать угольные базы. Его личные качества - деловитость, трудолюбие и точность при выполне- 
нии порученных работ, а также оперативность будут способствовать успеху организации двух угольных станций, а именно: в гавани Диксон и на острове Котельном. Сопровождать Коломейцева мог бы Расторгуев, которого все еще не покидает мысль об отпуске. До нового года этот план должен быть окончательно продуман». Наконец, 3 февраля сделана запись: «... Коломейцев уехал сегодня в 11 часов 25 минут дня. Я слишком устал, чтобы осознать свою радость, что тяжелый угольный вопрос встал на путь разрешения и что все связанное с ним завершится! Теперь жизнь пойдет по-новому, и я смогу остаток зимы наслаждаться приятным трудом, экскурсиями и т.д. ... Надеюсь, что Коломейцев, не рискуя жизнью, своевременно достигнет места своего назначения, а Расторгуев сможет вернуться ко мне... Вместо лейтенанта Н.Н. Коломейцева я назначил лейтенанта Ф.А. Матисена командиром яхты «Заря». Таймырский залив, 768' с.ш., $95^{\circ} 6^{\prime}$ в.д. $21 . I$ - 3.II.1901. Э. Толль».

\section{ЗАКЛЮЧЕНИЕ}

Обработка и опубликование научных результатов РПЭ продолжалась Комиссией для снаряжения Русской полярной экспедиции вплоть до 1916 года, уже после кончины академика Ф.Б. Шмидта в ноябре 1908 года [18]. Комиссия прекратила свою деятельность «как вследствие недостатка средств, так и частью вследствие полнаго прекращения, частью затруднения общения со специалистами и другими лицами [в] переживаемое ныне тяжелое время...».

В последующих статьях, посвященных итогам РПЭ, будет проведен анализ этих материалов, позволяющий установить целый ряд случайных и закономерных событий, на первый взгляд кажущихся совершенно незначительными, но оказавшимися решающими при реализации задач РПЭ.

\section{ЛИТЕРАТУРА}

1. Архивное дело Г.иМ.М.И.А.Н. № 56. Геологического и Ми нералогического музея имени Императора Петра Великого Императорской Академии наук (ГиММ ИАН): Толль, Э.В. (КП1849 / АР-4-6 и др.) // Фонды Рудно-петрографического музея ИГЕМ РАН.

2. Бичерова Н.С., Полякова М.В. История создания и этапь развития головной библиотеки отделения РАН «Науки о Земле» за период 1865-1970 ге. // Вклад информационно-библиотечной системы РАН в развитие отечественного библиотековедения, информатики и книговедения: Юбилейный науч. сб., посв. 100-летию Информационно-библиотечного совета РАН. - Новосибирск. 2011. С. 308-315.

3. Вилькицкий Б.А. Последнее плавание и открытия Экспедиции Ледовитого океана / Забытые герои Арктики. Люди и ледоколы // Автор-составитель Н.А. Кузнецов. - М.: Паулсен, 2018. C. $371-381$

4. Виттенбура П.В. Жизнь и научная деятельность Э.В. Толля. - М.-Л.: Изд. АН СССР. 1960. 246 с

5. Врангель Ф.Ф. Русская Полярная Экспедиция. СПб.: Главное Гидрографическое Управление: Тип. ИАН. 1901. 28 с.

6. Докучаев А.Я., Крехан Г.-Р., Каргин А.В. и др. Выдающийся исследователь Арктики Э.В. Толль в документах и материалах Рудно-петрографического музея (ИГЕМ РАН, Москва) // Новые данные о минералах. 2016. Вып. 51. С. 152-162.

7. Евгенов Н.И., Купецкий В.Н. Полярная экспедиция на ледоколах «Таймыр» и «Вайгач» в 1910-1915 годах. СПб.: ГеоГрафр. 2013. 312 c.

8. Иванов В.Л. Архипелаг двух морей. М.: Мысль. 1979. 160 с. 9. Известия Императорской Академии наук. 1915. № 3. VI ceрия. С. 195

10. Известия Императорской Академии наук. 1915. № 7. VI серия. С. 563-564.

11. Коломейцов Н.H. Отчеты о работах Русской Полярной Экспедиции, находящейся под начальством барона Толля. II. Отчет лейтенанта Коломейцова о санных поездках и об устройстве угольнаго склада на острове Кузькин (Порт Диксона) // Оттиск из Известий Императорской Академии Наук. T. XV. № 5. (Декабрь 1901). С.-Петербуре: Типография Императорской Академии наук. 1902. C. 499-517 // URL: Российская национальная библиотека (РНБ), Национальная электронная библиотека (НЭБ) // URL: http://нЭб.pqb/.

12. Колчак А.В. и др. Отчет о работах Русской Полярной Экспедиции, находящейся под начальством барона Толля. VII. Предварительный отчет начальника экспедиции на землю Беннетm для оказания помощи барону Толлю. VIII. Краткий отчет барона Э.В. Толля. IX. Отчет начальника экспедиции на Ново-Сибирские острова для оказания помощи барону Толлю // Изв. Имп. Акад. Наук. T. XX. № 5. 1904. C. 149-194 // URL: Российская национальная библиотека (РНБ), Национальная электронная библиотека (НЭБ) // URL: http://нэб.рф/.

13. Колчак А.В. Протоколы заседаний чрезвычайной след ственной комиссии по делу Колчака (Стенографический отчеm). 1920 // URL: http://royallib.ru.

14. Колчак А.В. Рукописи. Санкт-Петербураский фрилиал Архива РАН (СПФ АРАН) Ф. 14. Оп. 1. Д. 30, 39, 43, 127, 221.

15. Кузнецов Н.А. В поисках Земли Санникова. Полярные экспедиции Толля и Колчака // Библиотека полярных исследований. М.: Паулсен. 2014. 35 с.

16. Матисен Ф.А. Донесение командира яхты «Заря» лейтенанта Ф.А. Матисена Августейшему Президенту Императорской Академии Наук (с 9 фототипическими таблицами и 1 картой) // Отчеты о работах Русской Полярной Экспедиции, находящейся под начальством барона Толля. СанктПетербуре: Тип. Императорской Академии наук. 1904. T. VI.

17. Нансен Фритьоф. Через Сибирь. - М.: Игра слов. 2012. $304 \mathrm{c}$.

18. Отчет Комиссии для снаряжения Русской Полярной экспедиции за 1916 год. Петроград: Типография Императорской Академии Наук. 1917. 3 с.

19. Равна Эйвинд. Через Сибирь с Нансеном. - М.: Паулсен. 2017. 304 c.

20. Сообщение доктора Л.М. Старокадомского. Плавание Ги дрографической экспедичии Северного Ледовитого океана в 1913 г. / Забытые герои Арктики. Люди и ледоколы // Авторсоставитель Н.А. Кузнецов. М.: Паулсен, 2018. С. 345-354.

21. Сухова Н.Г. А.А. Бялыницкий-Бируля: письма из Русской полярной экспедиции: Подготовка к публикации и комментарии // Историко-биологические исследования. 2014. Том 6. № 1. C. 84-97.

22. Толль Э.В. Плавание на яхте «Заря». - М.: Географиздат. 1959. $340 \mathrm{C.}$

23. Толь э. Ископаемые ледники Ново-Сибирских островов, их отношение к трупам мамонтов и к ледниковому периоду // Зап. Имп. РГО по общей географии. T. ХХXII. № 1. СПб.: Tuп. Имп. АН. 1897. 139 с. // URL: Государственная публичная историческая библиотека (ГПИБ). Российская государственная библиотека // URL: http://rsl.ru/

24. Чайковский Ю.В. Возвращение лейтенанта Колчака. К 100-летию русской полярной экспедиции (1900-1903) // Bестник РАН. 2002. № 2. С. 152-161.

25. Черкашин Н.A. Командоры полярных морей. - М.: Вече, 2017. 464 c. 
THE RUSSIAN POLAR EXPEDITION (1901-1902): MATERIALS FROM THE ARCHIVE OF THE ORE AND PETROGRAPHIC MUSEUM OF IGEM RAN (INSTITUTE OF GEOLOGY OF ORE DEPOSITS OF THE RUSSIAN ACADEMY OF SCIENCES) AND THE LIBRARY COLLECTION OF GEOLOGICAL LITERATURE OF BEN RAN (THE LIBRARY ON NATURAL SCIENCE OF THE RUSSIAN ACADEMY OF SCIENCES)

\title{
PART 1. THE RUSSIAN POLAR EXPEDITION (1901-1902): GOALS AND OBJECTIVES
}

A.Ya. Dokuchaev, G.-R.Krehahn, A.V. Kargin, F.V. Kulakov, E.B. Kurdyukov, A.B.

Leksin, K.V. Lobanov, M.V. Polyakova, V.N. Smol'yaninova and E.V. Yutkina (The Federal state budget organization of science Institute of geology of ore deposits, petrography, mineralogy and geochemistry of Russian Academy of Sciences (IGEM RAS))

\begin{abstract}
The archive of the Ore and Petrographic Museum of the Institute of Geology of Ore Deposits, Petrography, Mineralogy, and Geochemistry (IGEM), Russian Academy of Sciences, preserves files inherited from the Peter the Great Geological and Mineralogical Museum named after Peter the Great of the Russian Imperial Academy of Science with unique documents written in the Russian, German, and Italian languages by numerous outstanding Russian and foreign researchers. The Library of Geological Literature of the Library on Natural Sciences of the Russian Academy of Sciences (BEN RAN) is based on the prints, journals and books from the library at the Mineralogical Museum, which was founded in 1880 by Acad. F.B. Schmidt.

Based on personal correspondence between the Head of the Russian Polar Expedition (RPE) E.V. Toll (also spelled as Tol) and the Presiding Officer of the Specialized Commission on Equipment for RPE at the Russian Imperial Academy of Sciences Acad. F.B. Schmidt, is held in the museum's archives, covers the events for the first time, that affected the achievement of the RPE objectives. Keywords: Russian Polar Expedition, Sannikov Land, E.V. Toll, F.B. Schmidt, N.N. Kolomeitsev, A.V. Kolchak, F.A. Matisen, Ore and Petrographic Museum at IGEM RAS, Library of Geological Literature at LNS RAS.
\end{abstract}

\section{REFERENCES}

1. Arkhivnoe delo G.iM.M.I.A.N. № 56. Geologicheskogo i Mineralogicheskogo muzeya imeni Imperatora Petra Velikogo Imperatorskoy Akademii nauk (GiMM IAN): Toll', E.V. (KP-1849 / AR-4-6 i dr.) // Fondy Rudno-petrograficheskogo muzeya IGEM RAN.

2. Bicherova N.S., Polyakova M.V. Istoriya sozdaniya i etapy razvitiya golovnoy biblioteki otdeleniya RAN «Nauki o Zemle» za period 1865$1970 \mathrm{gg}$. // Vklad informatsionno-bibliotechnoy sistemy RAN v razvitie otechestvennogo bibliotekovedeniya, informatiki i knigovedeniya: Yubileynyy nauch. sb., posv. 100-letiyu Informatsionno-bibliotechnogo soveta RAN.- Novosibirsk. 2011. S. 308-315.

3. Vil'kitskiy B.A. Poslednee plavanie i otkrytiya Ekspeditsii Ledovitogo okeana / Zabytye geroi Arktiki. Lyudi i ledokoly // Avtor-sostavitel' N.A. Kuznetsov. M.: Paulsen, 2018. S. 371-381.

4. Vittenburg P.V. Zhizn' i nauchnaya deyatel'nost' E.V. Tollya. M.-L.: Izd. AN SSSR. 1960. 246 s.

5. Vrangel' F.F. Russkaya Polyarnaya Ekspeditsiya. SPb.: Glavnoe Gidrograficheskoe Upravlenie: Tip. IAN. 1901.28 s.

6. Dokuchaev A. Ya., Krekhan G.-R., Kargin A.V. i dr. Vydayushchiysya issledovatel' Arktiki E.V. Toll' v dokumentakh i materialakh Rudnopetrograficheskogo muzeya (IGEM RAN, Moskva) // Novye dannye o mineralakh. 2016. Vyp. 51. S. 152-162.

7. Evgenov N.I., Kupetskiy V.N. Polyarnaya ekspeditsiya na ledokolakh «Taymyr» i «Vaygach» v 1910-1915 godakh. SPb.: GeoGraf. 2013. $312 \mathrm{~s}$.

8. Ivanov V.L. Arkhipelag dvukh morey. M.: Mysl'. 1979. $160 \mathrm{~s}$

9. Izvestiya Imperatorskoy Akademii nauk. 1915. № 3. VI seriya. S. 195

10. Izvestiya Imperatorskoy Akademii nauk. 1915. № 7. VI seriya. S. 563-564.

11. Kolomeytsov N.N. Otchety o rabotakh Russkoy Polyarnoy Ekspeditsii, nakhodyashcheysya pod nachal'stvom barona Tollya. II. Otchet leytenanta Kolomeytsova o sannykh poezdkakh i ob ustroystve ugol'nago sklada na ostrove Kuz'kin (Port Diksona) // Ottisk iz Izvestiy Imperatorskoy Akademii Nauk. T. XV. № 5. (Dekabr' 1901). S.-Peterburg: Tipografiya Imperatorskoy Akademii nauk. 1902. S. 499-517 // URL: Rossiyskaya natsional'naya biblioteka (RNB), Natsional'naya elektronnaya biblioteka (NEB) // URL: http://neb.rf/.

12. Kolchak A.V. i dr. Otchet o rabotakh Russkoy Polyarnoy Ekspeditsii, nakhodyashcheysya pod nachal'stvom barona Tollya. VII. Predvaritel'nyy otchet nachal'nika ekspeditsii na zemlyu Bennett dlya okazaniya pomoshchi baronu Tollyu. VIII. Kratkiy otchet barona E.V. Tollya. IX. Otchet nachal'nika ekspeditsii na Novo-Sibirskie ostrova dlya okazaniya pomoshchi baronu Tollyu // Izv. Imp. Akad. Nauk. T. XX. No 5. 1904. S. 149-194 // URL: Rossiyskaya natsional'naya biblioteka (RNB), Natsional'naya elektronnaya biblioteka (NEB) // URL: http://neb.rf/. 13. Kolchak A.V. Protokoly zasedaniy chrezvychaynoy sledstvennoy komissii po delu Kolchaka (Stenograficheskiy otchet). 1920 // URL: http://royallib.ru.

14. Kolchak A.V. Rukopisi. Sankt-Peterburgskiy filial Arkhiva RAN (SPF ARAN) F. 14. Op. 1. D. 30, 39, 43, 127,221

15. Kuznetsov N.A. V poiskakh Zemli Sannikova. Polyarnye ekspeditsii Tollya i Kolchaka // Biblioteka polyarnykh issledovaniy. M.: Paulsen. 2014. $35 \mathrm{~s}$

16. Matisen F.A. Donesenie komandira yakhty «Zarya» leytenanta F.A. Matisena Avgusteyshemu Prezidentu Imperatorskoy Akademii Nauk (s 9 fototipicheskimi tablitsami i 1 kartoy) // Otchety o rabotakh Russkoy Polyarnoy Ekspeditsii, nakhodyashcheysya pod nachal'stvom barona Tollya. Sankt-Peterburg: Tip. Imperatorskoy Akademii nauk. 1904. T. VI.

17. Nansen Frit'of. Cherez Sibir'. M.: Igra slov. 2012. 304 s.

18. Otchet Komissii dlya snaryazheniya Russkoy Polyarnoy ekspeditsii za 1916 god. Petrograd: Tipografiya Imperatorskoy Akademii Nauk. 1917. 3 s.

19. Ravna Eyvind. Cherez Sibir's Nansenom. M.: Paulsen. 2017. 304 s.

20. Soobshchenie doktora L.M. Starokadomskogo. Plavanie Gidrograficheskoy ekspeditsii Severnogo Ledovitogo okeana v 1913 g. / Zabytye geroi Arktiki. Lyudi i ledokoly // Avtor-sostavitel' N.A. Kuznetsov. M.: Paulsen, 2018. S. 345-354.

21. Sukhova N.G. A.A. Byalynitskiy-Birulya: pis'ma iz Russkoy polyarnoy ekspeditsii: Podgotovka k publikatsii i kommentarii // Istorikobiologicheskie issledovaniya. 2014. Tom 6. № 1. S. 84-97.

22. Toll' E.V. Plavanie na yakhte "Zarya». M.: Geografizdat. 1959. 340 s.

23. Tol' E. Iskopaemye ledniki Novo-Sibirskikh ostrovov, ikh otnoshenie k trupam mamontov i k lednikovomu periodu // Zap. Imp. RGO po obshchey geografii. T. XXXII. № 1. SPb.: Tip. Imp. AN. 1897. 139 s. I/ URL: Gosudarstvennaya publichnaya istoricheskaya biblioteka (GPIB). Rossiyskaya gosudarstvennaya biblioteka // URL: http://rsl.ru/

24. Chaykovskiy Yu.V. Vozvrashchenie leytenanta Kolchaka. K 100-letiyu russkoy polyarnoy ekspeditsii (1900-1903) // Vestnik RAN. 2002. № 2. S. 152-161.

25. Cherkashin N.A. Komandory polyarnykh morey. M.: Veche, 2017. 464 s. 